\title{
The Need for Interpretative Methods in International Law
}

\begin{abstract}
Misuse of international law by national jurisdictions may have farreaching negative consequences beyond the specific facts of the case over the long term. Such misuse as this promotes development of bad law, which runs the risk of being cited and adopted by other national jurisdictions. ${ }^{981}$
\end{abstract}

In Parts 1 and 2, I have analyzed what interpretation is, and why domestic courts' interpretations are central to international law. I now move on to a third question: how must domestic courts interpret international law?

In the third part of this book, I argue that international law requires States to use specific methods to interpret these obligations, including via their courts, and that there are good reasons for imposing such a requirement on them. These reasons are primarily connected to the importance of lawful interpretation. However, they can also be linked to the virtues of predictable, clear, and consistent legal reasoning (supra, Introduction, section 3 ).

While the aforementioned claim may seem obvious and uncontroversial, States' duty to respect interpretative methods is often misunderstood, disregarded, or swept aside in practice and scholarship, as I will show. Many scholars (and even judges) express skepticism about interpretative methods. They argue that methods are vague and cannot constrain judges, that they are defined by the very actors whose powers they are supposed to harness, and that an emphasis on method neglects interpretative outcomes. In this chapter, I argue that such skepticism is unwarranted.

981 Weill (n 61) 67. 
The chapter is structured as follows. First, I compare judicial interpretation to interpretation in other domains. This will help me show why legal interpretation in particular needs to be governed by specific methods (2). I also briefly retrace the development of interpretative methods in domestic and international law (3). I then provide arguments for having mandatory interpretative methods in domestic and international law (4), examine several objections that have been raised against interpretative methods (5), and conclude (6).

In this chapter, I do not yet examine the specific methods States and their courts must use. This issue is analyzed in Chapter 6 (infra). Nor do I examine whether methods are legitimate or morally justified all things considered. Still, the reasons I cite for requiring States and officials to respect the law's methods provide elements of such a theory of legitimacy.

\section{Why Does the Law Need Interpretative Methods? a Comparison With Interpretation Outside the Law}

(Dis)analogies between legal (and especially judicial) interpretation and other interpretative practices - eg the interpretation of religious texts, artworks, and social relationships - are frequently relied upon to conceptualize the interpretation of domestic law. ${ }^{982}$ Such parallels have also been drawn regarding international law. ${ }^{983}$ These comparisons are insightful. They can help us understand why constraining judicial interpretation through methods is so important.

Many analogies have been used in legal scholarship to highlight the ambivalence of judicial interpretation. It is an activity that is both constrained and free. On the one hand, legal (and especially judicial) interpretation is constrained, both legally and otherwise. ${ }^{984}$ This diagnosis also applies to

982 Dworkin (n 77) 7; Stanley Fish, Is There a Text in This Class? The Authority of Interpretive Communities (Harvard University Press 1980); Cover (n 208); von Savigny (n 761) 212; Pierre Moor, 'Dire le droit' (1997) 35 Revue européenne des sciences sociales 33; Bankowski and others (n 132) 12 f; Frankfurter (n 4); Barradas de Freitas (n 127).

983 Klabbers, 'Virtuous Interpretation' (n 93); Michael Waibel, 'Demystifying the Art of Interpretation' (2011) 22 European Journal of International Law 571. For a recent piece on the use of metaphors in international law in general, see Maks Del Mar, 'Metaphor in International Law: Language, Imagination and Normative Inquiry' (2017) 86 Nordic Journal of International Law 170.

984 'Largumentation des juristes et ses contraintes (2)' (2012) 55 Droits; 'Largumentation des juristes et ses contraintes (1)' (2011) 54 Droits; François Ost, 'Linterprétation des lois: un jeu sous contraintes' (2011) <www.philodroit.be/IMG/pdf/Ost.pdf>; Troper, Champeil-Desplats, and Grzegorczyk (n 8o). 
international law, ${ }^{985}$ and it is shared by most legal scholars. ${ }^{986}$ To emphasize legal (and other) constraints on interpretative freedom, the metaphor of the game (which, like the law, is a rule- [or, to put it more accurately, a norm-] governed activity) has attracted both domestic ${ }^{987}$ and international legal theorists. ${ }^{988}$ François Ost for instance argues that statutory interpretation is 'a game within constraints'. ${ }^{989}$ Hart shows that most games are governed by predetermined rules, and that playing them is not equal to playing 'scorer's discretion. ${ }^{990}$ On the other hand, interpretation is also characterized by the freedom judges enjoy within the 'rules of the game'. Kelsen notes that 'the law to be applied constitutes only a frame within which several applications are possible, whereby every act is legal that stays within the frame'. ${ }^{991}$ Methods are 'a frame without a picture' 992 that limits, but also empowers interpreters. In the international realm, the ILC has famously emphasized that treaty interpretation is 'to some extent an art, not an exact science.' 993

Scholars have voiced concerns about hasty analogies between legal interpretation and interpretation outside the law ${ }^{994}$ - and rightly so. Analogies risk obfuscating rather than facilitating analytical thinking. They can overlook what makes legal interpretation unique. The widespread use of analogies may be a sign that we struggle to understand legal interpretation. However, analogies are also useful to stimulate analytical thinking. ${ }^{995}$ We can better understand

985 Bianchi, Peat, and Windsor (n 126 ).

986 Eg Kennedy, 'Freedom and Constraint in Adjudication: A Critical Phenomenology' (n 75).

987 Eg Michel Troper, Véronique Champeil-Desplats, and Christophe Grzegorczyk, 'Introduction' in Michel Troper, Véronique Champeil-Desplats, and Christophe Grzegorczyk (eds), Théorie des contraintes juridiques (LGDJ/Bruylant 2005) 2 f.

988 Bianchi, Peat, and Windsor (n 126); Lorenzo Gradoni, “The International Court of Justice and the International Customary Law Game of Cards' in Mads Andenas and Eirik Bjorge (eds), A Farewell to Fragmentation: Reassertion and Convergence in International Law (Cambridge University Press 2015); Emer de Vattel, Le droit des gens ou principes de la loi naturelle appliqués à la conduite et aux affaires des nations et des souverains (Librairie de Guillaumin et Cie 1863) 465. For a critique, see Odile Ammann, 'International Legal Interpretation as a Game: A Compelling Analogy?' (2016) Harvard International Law Journal (online edition).

989 Ost (n 983).

990 Hart (n 78$) 142$.

991 Hans Kelsen, The Pure Theory of Law (University of California Press 1967) 351.

992 Frederick Schauer, 'The Dilemma of Ignorance: PGA Tour, Inc. v Casey Martin' (2001) 2001 Supreme Court Review 267, 267.

993 ILC, 'Draft Articles on the Law of Treaties With Commentaries' (n 783) 218.

994 Eg Richard A Posner, Law and Literature: A Misunderstood Relation (Harvard University Press 1988); Haig Bosmajian, Metaphor and Reason in Judicial Opinions (Southern Illinois University Press 1992). See also Jan Klabbers, 'International Legal Histories: The Declining Importance of Travaux Préparatoires in Treaty Interpretation?' (2003) 5o Netherlands International Law Review 267, 272.

Shapiro (n 196) 19. 
judicial interpretation, and why it needs to be governed by methods, by carefully comparing (2.1) and contrasting it (2.2) with interpretation outside legal practice.

\subsection{Similarities}

Legal (and especially judicial) interpretation and the interpretation of other objects than laws share four main similarities: (i) they are constrained by context, (ii) they are governed by idiosyncratic methods, (iii) they leave room for different interpretative results, and finally, (iv) they are accompanied by reasons stating why a given interpretation is correct.

First, interpretation does not occur in a vacuum, but is constrained by context. Ludwig Wittgenstein has famously pointed out that 'meaning is use', and that it hinges on the canons that a practice generates. Susan Sontag notes that photographers are 'haunted by tacit imperatives of taste and conscience.'996 This applies to interpretation in the arts more generally. ${ }^{997}$ In the legal realm, the legal norms that require courts to use specific methods are secondary norms and therefore, before anything else, customary norms (on the Hartian notion of secondary norms, see infra, 3.2). Moreover, what constitutes highquality judicial reasoning is defined by legal practice, besides being a corollary of the legal and moral principle of the rule of law (see also supra, Introduction, section 3$)^{998}$

Secondly, different interpretative domains have different idiosyncratic methods. A method is 'a systematic procedure, technique, or mode of inquiry employed by or proper to a particular discipline or art' (emphasis added). ${ }^{999}$ Methods are ways through which the interpreter can achieve good results by the standards of this interpretative practice, even if this does not rule out legitimate disagreement about how the object must be interpreted. Early treatises of general hermeneutics, for instance, intended to help interpreters exclude 'wrong' meanings and select 'true' ones. ${ }^{1000}$ In international law, Hugo Grotius

996 Susan Sontag, On Photography (Picador 1977) 6.

997 Eg Kendall L Walton, Marvelous Images: On Values and the Arts (Oxford University Press 2008) $204 \mathrm{f}$.

998 Michael Klarman argues that 'the principal constraints on constitutional interpretation derive from social and political context, not from constitutional text or tradition', see Klarman (n 831) 1742. François Gény writes that 'we [lawyers] are dominated, without our knowledge, by authority and tradition, and, if I may say so, by this professional heredity, which envelops and embraces us like some sort of shirt of Nessus'. See François Gény, Méthode d'interprétation et sources en droit privé positif (2nd edn, LGDJ 1919) 51.

$999<$ <ww.merriam-webster.com/dictionary/method>.

1000 Bjørn Ramberg and Kristin Gjesdal, 'Hermeneutics', Stanford Encyclopedia of Philosophy $(2005)<$ plato.stanford.edu/entries/hermeneutics $>$. 
and his followers considered methods necessary to solve disputes and to determine the true meaning of international law. ${ }^{1001}$

Thirdly, even within a given context, there are typically different ways to interpret an object while remaining within the constraints defined by the context. One method (eg textual interpretation) may be applied differently by different interpreters, with different results. Moreover, there are often various ways of choosing among the results yielded by different methods to determine the meaning of the interpretative object. Even within a given 'interpretive community',1002 there can be various good conceptions of what a good interpretation is ${ }^{1003}$ and, therefore, different incompatible, yet good interpretations of a given object. ${ }^{1004}$ Of course, methodological disagreement does not necessarily yield incompatible interpretations, and vice versa. Disputes about interpretative methods already divided the Roman jurists, ${ }^{1005}$ and methods have also been 'the subject of acute debate and controversy' in international law. ${ }^{1006}$ While these divergences hinge on deeper disagreements about issues of moral philosophy, they primarily express themselves via methodological feuds. ${ }^{1007}$ It is important to emphasize that there may be (i) 'interpretations' that are not actually interpretations, even if they are presented as such, and (ii) bad interpretations. Thus, not every disagreement is a legitimate one, unless it involves incompatible, yet good interpretations.

1001 David J Bederman, 'Grotius and His Followers on Treaty Construction' (2001) 3 Journal of the History of International Law 18, 22.

1002 According to Stanley Fish, an interpretive community is formed by 'those who share interpretive strategies not for reading but for writing texts, for constituting their properties'. See Fish, Is There a Text in This Class? The Authority of Interpretive Communities (n 982) 5 .

1003 Raz, 'Normativity: The Place of Reasoning' (n 978) 146. See also Sontag (n 996) 115 f; 173 f; Monroe C Beardsley and William K Wimsatt, 'The Intentional Fallacy' in Joseph Margolis (ed), Philosophy Looks at the Arts (3rd edn, Temple University Press 1987).

1004 Raz, Between Authority and Interpretation: On the Theory of Law and Practical Reason (n 78$) 231$.

1005 This is illustrated by the antagonism between the Sabinians (who endorsed an early form of formalism) and the Proculians (whose conception of legal interpretation was more pragmatic). See Peter Stein, 'Interpretation and Legal Reasoning in Roman Law' (1995) 7o Chicago-Kent Law Review 1539, $1544 \mathrm{f}$.

1006 Gerald Fitzmaurice, 'The Law and Procedure of the International Court of Justice, 1951-4: Treaty Interpretation and Other Treaty Points' (1957) 33 British Yearbook of International Law 203, 204. See also (regarding CIL) Petersen (n 73) $6 \mathrm{ff}$.

1007 Sunstein, 'There Is Nothing That Interpretation Just Is' (n 207); Robert Post, 'Theories of Constitutional Interpretation' (1990) 30 Representations 13. 
Lastly, the merits of an interpretation cannot be evaluated unless the interpretation is accompanied by reasons explaining why this interpretation is correct. 1008

\section{$2.2 \quad$ Differences}

Three differences between legal (and more specifically judicial) interpretation and interpretation outside the law explain why interpretative methods and predictable, clear, and consistent reasoning are particularly important in judicial decision-making. These differences concern (i) the respective stakes of these activities, (ii) the authority of judicial interpretation, and (iii) judges' duty to settle disputes.

First, the stakes of judicial interpretation differ from those of interpretation in other domains. As Robert Cover notes, 'legal interpretation takes place in a field of pain and death.'1009 Laws regulate virtually every aspect of human life, ${ }^{1010}$ and domestic rulings can have implications for the entire legal order. They often settle controversial moral issues, and they can have far-reaching implications for the law's subjects, eg in terms of social security, economic policy, or fundamental rights. This explains why constitutional interpretation has been a central preoccupation in legal theory. Interpretation outside the law, by contrast, does not play a comparable part in structuring the life of a society.

Second, judicial interpretations are legally authoritative for the parties to the dispute (and, in some jurisdictions, beyond the particular case). They aim at guiding the behavior of their subjects, and they exclude other reasons to act that these subjects might have. In non-legal domains, interpretations do not share this preemptive, exclusionary normative force. In the arts, interpreters claim that their interpretations are valid, but they can merely strive (if at all) to 'woo the consent of everyone else.'.111

Third, judges are dispute settlers. We disagree about the meaning of plays, books, paintings, and the law. Yet in the latter case, 'a common basis for action

1008 Raz, Between Authority and Interpretation: On the Theory of Law and Practical Reason (n 78 ) 230. See also Timothy Endicott, 'Interpretation and Indeterminacy: Comments on Andrei Marmor's Philosophy of Law' (2014) 10 Jerusalem Review of Legal Studies 46.

1009 Robert M Cover, 'Violence and the Word' (1986) 95 Yale Law Journal 1601.

1010 Barradas de Freitas (n 127) 46.

1011 This expression is used by Hannah Arendt, "The Crisis in Culture: Its Social and Its Political Significance', Between Past and Future: Eight Exercises in Political Thought (Penguin Books 2006) 222; David Luban, 'Arendt at Jerusalem' (2015) 30. See Immanuel Kant, Kant's Critique of Judgment, Translated With Introduction and Notes by J. H. Bernard (2nd edn, Macmillan 1914) 92, § 19. 
has to be forged in the heat of our disagreements.1012 Granted, outside the law, interpretive communities rely on epistemic authorities to ascertain the meaning of interpretative objects. Hume for instance deemed experts the 'real judges' of an artwork's aesthetic quality. ${ }^{1013}$ Yet expert opinions do not cordon off other interpretations, as judicial interpretations do.

Due to the high stakes, legal authority, and finality of judicial interpretation, judges yield tremendous institutional power. This explains why domestic and international law seek to harness this power through interpretative norms.

The Origins of Interpretative Methods in Domestic and International Law

In this book, I argue that States and their courts must respect the interpretative methods of international law, and that they should meet the standards of good (high-quality) legal reasoning. When making such an argument, it seems essential to have at least a basic understanding of how interpretative methods have developed in domestic and international law, and of the relationship between the respective methods of these two bodies of law. It is important to clarify at the outset that a comprehensive historical account is beyond the scope of this chapter. Excellent research already exists on this topic. ${ }^{1014} \mathrm{My}$ goal is merely to show that interpretative methods are nothing new. They pervade legal practice. This account will be particularly helpful when analyzing arguments in favor of, and criticisms raised against, interpretative methods (infra, sections 4-5). As mentioned, I do not yet examine specific methods. I address this issue in Chapter 6 (infra).

How did legal norms prescribing the use of interpretative methods emerge? As Samantha Besson writes, 'one might reasonably suppose that many of the questions of legal philosophy are best approached in the first instance via their application to municipal state legal systems, which are both more familiar and more highly developed, before advancing to their international

1012 Waldron, 'The Core of the Case Against Judicial Review' (n 746) 1370. See also Hart's observation that uncertainty in particular cases makes primary norms inefficient: Hart (n 78 ) 93 .

1013 David Hume, 'Of the Standard of Taste' in Charles W Eliot (ed), English Essays: From Sir Philip Sidney to Macaulay - The Harvard Classics, Vol 27 (Collier 1910).

1014 For a historical analysis of interpretative methods in domestic law, see Benoît Frydman, Le sens des lois: Histoire de l'interprétation et de la raison juridique (Bruylant 2005). For international law, see David J Bederman, Classical Canons: Rhetoric, Classicism and Treaty Interpretation (Applied Legal Philosophy) (Ashgate 2001). 
counterparts.' ${ }^{1015}$ I hence examine the aforementioned issue for both domestic (3.1) and international law (3.2). I also clarify the relationship between interpretative methods in domestic and international law (3.3).

\subsection{Domestic Law}

Domestic interpretative methods have existed for centuries, and scholarship on how to interpret domestic laws - a traditional question of legal theory and philosophy - is prolific. In continental Europe, the first scholarly efforts to spell out the 'methods' of domestic legal interpretation date back to the 19th century. These efforts were based on the conception of law as a 'science', with a methodology of its own right. ${ }^{1016}$ Savigny's 'four elements' doctrine, ${ }^{1017}$ which is at the root of the methods Swiss and other domestic courts ${ }^{1018}$ use to interpret domestic laws (including in common law countries), ${ }^{1019}$ builds upon the understanding of law as a scientific endeavor ('Rechtswissenschaft'). ${ }^{1020}$ While this conception is less compelling today, it still surfaces in contemporary scholarship. ${ }^{1021}$ Savigny's four methods aim at helping the interpreter ascertain domestic laws. ${ }^{1022}$ François Gény, in his early 2oth-century analysis of the interpretation of French private law, notes that these 'traditional' ${ }^{1023}$ methods developed alongside processes of codification. ${ }^{1024}$ Many of them ensure judicial accountability towards the legislature. Calls for a renewal of legal and judicial methods increased after

1015 Samantha Besson, 'Moral Philosophy and International Law' in Florian Hoffmann and Anne Orford (eds), The Oxford Handbook of International Legal Theory (Oxford University Press 2016) 387. International law and domestic constitutional law, in particular, share more features than is often assumed: Jack L Goldsmith and Daryl Levinson, 'Law for States: International Law, Constitutional Law, Public Law' (2009) 122 Harvard Law Review 1791. HLA Hart even considered that a 'range of principles, concepts, and methods which are common to both municipal and international law, [...] make the lawyers' technique freely transferable from the one to the other'. Hart (n 78 ) 237.

1016 Gény (n 998); Frydman (n 1014) 20.

1017 von Savigny (n 761) $212 \mathrm{ff}$.

1018 Michal Bobek, Comparative Reasoning in European Supreme Courts (Oxford University Press 2013).

1019 The Interpretation of Statutes (n 54) 12.

1020 von Savigny (n 761) 206 ff. See also Friedrich Karl von Savigny, Vom Beruf unsrer Zeit für Gesetzgebung und Rechtswissenschaft (3rd edn, JCB Mohr 1840).

1021 Ernst Kramer, 'Konvergenz und Internationalisierung der juristischen Methode' in Académie des privatistes européens (ed), A l'Europe du troisième millénaire: Mélanges offerts à Giuseppe Gandolfi à l'occasion du dixième anniversaire de la fondation de l'Académie (Giuffrè 2014) 167.

1022 von Savigny (n 761$) 207$.

1023 For a critique of this characterization: Frydman (n 1014) 17.

1024 Gény (n 998) 23. See also Waibel, 'Principles of Treaty Interpretation: Developed for and Applied by National Courts?' (n 183) $26 \mathrm{f}$. 
the traumatic experience of Nazi and communist dictatorships ${ }^{1025}$ and their 'dreadful jurists'.1026

In the United States, methods of legal (and especially constitutional) interpretation are deemed means for 'domesticating the judges' personal preferences.'.027 These methods were developed by the courts which, especially in the years that followed their creation, had to secure their institutional legitimacy. After some bold yet widely acclaimed decisions of the Warren Court, ${ }^{1028}$ many jurists felt the urge to demonstrate that such rulings were 'law, not just politics',1029 ie, that they were in accordance with the law and based on predictable, clear, and consistent judicial reasoning. us lawyers associate the requirement to follow interpretative methods with courts' duty to protect the rule of law, ${ }^{1030}$ 'to say what the law is'. ${ }^{1031}$ Some methods are acceptable, while others 'are not part of [US] legal grammar'.1032 Robert Summers and Neil MacCormick list eleven 'argument types'1033 that courts in the United States and elsewhere use in statutory interpretation. These argument types fall into four categories: linguistic, systemic, teleological/evaluative, and 'transcategorical' (or 'argument from intention'). ${ }^{1034}$ In England as well, methods of statutory interpretation are judge-made. ${ }^{1035}$

This short account suggests that interpretative methods are part of domestic legal practice. They are used as guides by officials ${ }^{1036}$ and by those who evaluate their practice. ${ }^{1037}$

1025 Gustav Radbruch, 'Gesetzliches Unrecht und übergesetzliches Recht' (1946) 1 Süddeutsche Juristenzeitung 105.

1026 Peter Gauch, 'Juristisches Denken. Wie denken Juristen?' in Heinrich Honsell and others (eds), Privatrecht und Methode: Festschrift für Ernst A. Kramer (Helbing \& Lichtenhahn 2004) $179 \mathrm{f}$.

1027 Tushnet (n 777) 50.

1028 Brown v. Board of Education of Topeka, 349 U.s. 294 (1955); Griswold v. Connecticut, 381 U.S. 479 (1965).

1029 Owen M Fiss, 'Objectivity and Interpretation' (1982) 34 Stanford Law Review 739, 741.

1030 Brewer (n 213).

1031 Marbury v. Madison, 5 U.s. (1 Cranch) 137 (1803), at 177.

1032 Bobbitt (n 171) 6.

1033 This meaning of the word 'argument type' differs from the one used in Chapter 2, 5.5 (supra).

1034 D Neil MacCormick and Robert S Summers, 'Interpretation and Justification' in D Neil MacCormick and Robert S Summers (eds), Interpreting Statutes: A Comparative Study (Aldershot 1991).

1035 The Interpretation of Statutes (n 54) 14.

1036 Michael J Klarman, 'Bush v. Gore Through the Lens of Constitutional History' (2001) 89 California Law Review 1721, 1723.

1037 Tushnet (n 777) 50. 


\subsection{International Law}

A seminal contribution to the understanding of interpretative methods is Hart's account of law as a union of primary and secondary norms. ${ }^{1038}$ In this formulation, primary norms are directed towards legal subjects and create rights and obligations. Secondary norms are customary norms that 'are all concerned with the primary rules themselves' 1039 : they clarify how primary norms are created, changed, and interpreted, ${ }^{1040}$ and they are addressed to legal officials. According to Hart, secondary norms, unlike primary norms, are not rights-conferring or duty-imposing, but 'power-conferring' norms. Yet Hart neglects that duty-imposing secondary norms do exist. ${ }^{1041}$ Norms that prescribe the use of specific interpretative methods do not merely confer powers: they constrain legal officials, even if these officials retain some degree of interpretative freedom.

Importantly for our purposes, Hart argued that international law lacked secondary norms. ${ }^{1042}$ Since secondary norms include norms about interpretative methods, and since Hart's position was that international law was not a system but a 'set of rules', his scholarship probably reinforced many in the idea that international law was defective compared to domestic law. ${ }^{1043}$

It is true that the VCLT's methods of treaty interpretation are the result of a 'difficult gestation process', and that the lack of a systematic, consistent international practice on the issue rendered their codification controversial. ${ }^{1044}$ The ILC has codified some methods (eg, most recently, the methods for identifying customary law), ${ }^{1045}$ and in 2015 , the ILA set up a 'Study Group on the

1038 Hart (n 78) ch vi. While Hart refers to 'rules', the umbrella term of 'norms' seems more accurate, as norms governing judicial interpretation include principles (Chapter 2, 5.2 and $5 \cdot 3$, supra). The union of primary and secondary norms constitutes a legal system, as opposed to a set of rules lacking common criteria of validity and modification, ibid 94 .

1039 See Hart (n 78) 94.

1040 Eg Thomas M Franck, 'Legitimacy in the International System' (1988) 82 American Journal of International Law 705, 751-752; Axel Marschik, 'Too Much Order? The Impact of Special Secondary Norms on the Unity and Efficacy of the International Legal System' (1998) 9 European Journal of International Law 212, 212.

1041 I am grateful to Timothy Endicott for bringing this point to my attention.

1042 Hart (n 78$) 214$.

1043 Mehrhad Payandeh, 'The Concept of International Law' (2010) 21 European Journal of International Law 967 .

1044 Jean-Marc Sorel and Valérie Boré-Eveno, 'Article 31' in Olivier Corten and Pierre Klein (eds), The Vienna Conventions on the Law of Treaties: A Commentary, Vol I (Oxford University Press 2011) $806 \mathrm{f}$.

1045 ILC, 'Draft Conclusions on Identification of Customary International Law, With Commentaries' (n 891). 
Content and Evolution of the Rules of Interpretation'. ${ }^{1046}$ Yet international law does have (and has always had) secondary norms, ${ }^{1047}$ an obvious example being the century-old norm pacta sunt servanda.

Granted, State practice pertaining to the formation and amendment of international law is scarce, barely detailed, and often inconsistent, ${ }^{1048}$ as is the practice of international courts, ${ }^{1049}$ but such difficulties also exist in domestic law. States (and their courts) ${ }^{1050}$ and international judges ${ }^{1051}$ do rely on textual, historical, systematic, and teleological interpretation, even if the use of these methods does not always satisfy the virtues of predictability, clarity, and consistency. International rulings are evaluated based on their interpretative methods, and methodological 'laxness' is frowned upon. ${ }^{1052}$ The ICJ for instance has been criticized for its 'delphic' methodology. ${ }^{1053}$ Similar benchmarks are applied to the practice of other international courts, ${ }^{1054}$ regional courts, ${ }^{1055}$ to States and domestic rulings, ${ }^{1056}$ and even to non-state actors. ${ }^{1057}$

1046 ILA, 'Preliminary Report of the ILA Study Group on the Content and Evolution of the Rules of Interpretation' (n 231).

1047 Murphy (n 84) 154 f; Waldron, 'International Law: "A Relatively Small and Unimportant" Part of Jurisprudence?' (n 79).

1048 Gradoni (n 988$) 383 \mathrm{f}$.

1049 See ibid $394 \mathrm{ff}$.

1050 Bond v. United States, 572 U.s. 844 (2014) (treaty law); BGE 138 II 524, at 3 and 4 (treaty law); BGE 132 III 661, at 4.4 (CIL).

$105^{1}$ Malgosia Fitzmaurice, 'The History of Article 38 of the Statute of the International Court of Justice: The Journey From the Past to the Present' in Samantha Besson and Jean d'Aspremont (eds), The Oxford Handbook on the Sources of International Law (Oxford University Press 2017) $19 \mathrm{f}$.

$105^{2}$ Zammit Borda (n 870) 66; Talmon (n 73).

1053 Sienho (n 73) 480. The expression was originally used by Mendelson (n 73) 67, 72.

1054 Marc Schack and Astrid Kjeldgaard-Pedersen, 'Striking the Balance Between Custom and Justice: Creative Legal Reasoning by International Criminal Courts' (2016) 16 International Criminal Law Review 913.

1055 On the ECtHR: Letsas (n 79). On the IACtHR: Lukas Lixinski, 'Treaty Interpretation by the Inter-American Court of Human Rights: Expansionism at the Service of the Unity of International Law' (2010) 21 European Journal of International Law 585. On the CJEU: Odermatt (n 140); Kuijper (n 179).

1056 Andrea Bianchi, 'Overcoming the Hurdle of State Immunity in the Domestic Enforcement of International Human Rights' in Benedetto Conforti and Francesco Francioni (eds), Enforcing International Human Rights in Domestic Courts (Brill/Nijhoff 1997) 405, 407; Aust and Nolte (n 47); Aust, Rodiles, and Staubach (n 140); Iovane (n 182).

1057 On the ICRC and UNHCR, respectively, see John B Bellinger and William J Haynes, 'A Us Government Response to the International Committee of the Red Cross Study Customary International Humanitarian Law' (2007) 89 International Review of the Red Cross 443; Bailliet (n 15). 
Long before the adoption of the VCLT, international lawyers used to emphasize the importance of States being methodical in their interpretations. ${ }^{1058}$ Hugo Grotius considered that methods were necessary to provide guidance to interpreters in finding the proper meaning of treaties. Like the ancient Greeks, on whose work he relied, ${ }^{1059}$ he thought that methods would reduce the likelihood that States would interpret agreements in a 'sophistic' way. ${ }^{1060}$ These rationales were subsequently endorsed by scholars such as Samuel Pufendorf, ${ }^{1061}$ Christian Wolff,1062 and Emer de Vattel. ${ }^{1063}$ All of them (perhaps somewhat unrealistically) believed that treaty interpretation ought to be governed by 'definite', 'precise' 'rules'.

In the late 19th and early 2oth century, international lawyers still emphasized interpretative methods, but the rationales had changed. The 19th century heralded the increasing dominance of legal positivism. Instead of focusing on good faith and other principles of justice, legal positivists emphasized procedure and methodology, and they endeavored to develop the law's scientific credentials. ${ }^{1064}$ Although more convincing reasons for requiring States to respect interpretative methods have gained traction since (infra, section 4), this scientism has not entirely disappeared. ${ }^{1065}$

1058 On the 'distant origins' of the VCLT's interpretative principles, see Alain Pellet, 'Canons of Interpretation Under the Vienna Convention' in Joseph Klingler, Yuri Parkhomenko, and Constantinos Salonidis (eds), Between the Lines of the Vienna Convention?Canons and Other Principles of Interpretation in Public International Law (Kluwer Law International 2018).

1059 It is worth noting that some rules of logic (such as ejusdem generis and generalia specialibus non derogant) can be traced back to Roman law. See Michael Waibel, 'The Origins of Interpretive Canons in Domestic Legal Systems' in Joseph Klingler, Yuri Parkhomenko, and Constantinos Salonidis (eds), Between the Lines of the Vienna Convention? Canons and Other Principles of Interpretation in Public International Law (Kluwer Law International 2018) 27.

106o Bederman (n 1001) 25. See also ibid 34.

1061 Pufendorf (n 177) $793 \mathrm{f}$.

1062 Christian Wolff, Jus gentium methodo scientifica pertractatum (Clarendon Press/H Milford 1934) 194.

1063 de Vattel (n 988) 461.

1064 Martti Koskenniemi, 'The Politics of International Law' (1990) 1 European Journal of International Law 4, 6; Jochen von Bernstorff, 'German Intellectual Historical Origins of International Legal Positivism' in Jean d'Aspremont and Jörg Kammerhofer (eds), International Legal Positivism in a Post-Modern World (Cambridge University Press 2014). See also Anne Orford, 'Scientific Reason and the Discipline of International Law' (2014) 25 European Journal of International Law 369; Gradoni (n 988) $387 \mathrm{ff}$.

1065 ILC, 'Fragmentation of International Law: Difficulties Arising From the Diversification and Fragmentation of International Law' (n 296). 
In 1949, Hersch Lauterpacht recommended that the ILC include the law of treaties 'within the orbit of codification' 1066 of international law. Codification, in his opinion, would systematize the methods of treaty interpretation. He considered that treaty interpretation was 'overgrown with the weed of technical rules of construction which can be used - and are frequently used - in support of opposing contentions'. ${ }^{1067}$ Lauterpacht combined natural lawyers' emphasis on good faith and the need to constrain State discretion with the legal positivists' concern to derive such constraints from State practice. ${ }^{1068}$ The work of the other Special Rapporteurs on the law of treaties (especially Gerald Fitzmaurice ${ }^{1069}$ and Humphrey Waldock) $)^{1070}$ confirms that interpretative methods were deemed valuable, and that they were reflected in international legal practice at the time. The ILC's work led to the adoption of the VCLT, which includes three provisions on treaty interpretation. ${ }^{1071}$ The Convention's approach to interpretation, based on which different interpretative arguments are 'thrown into the crucible,,1072 preserves flexibility, thereby responding to States' concerns. ${ }^{1073}$ At the same time, it clarifies the principles of treaty interpretation, and hence defines interpretative constraints.

As is the case with treaty law, State practice shows that CIL too is ascertained based on interpretative canons, even if this practice can be criticized

1066 Hersch Lauterpacht, 'Survey of International Law in Relation to the Work of Codification of the International Law Commission, Memorandum Submitted by the Secretary-General of the United Nations' (1949) $5^{2}$.

1067 See ibid.

1068 Legal positivists such as Lassa Oppenheim emphasized that interpretative methods were to be derived from the practice of States (as opposed to principles of natural law), although they also thought that such methods were valuable and 'enable[d] a universally recognized construction of the treaties concerned'. See Lassa Oppenheim, 'The Science of International Law: Its Task and Method' (1908) 2 American Journal of International Law 313,35 .

1069 ILC, 'Second Report on the Law of Treaties by Mr. G. G. Fitzmaurice, Special Rapporteur' (1957) UN Doc A/CN.4/107; ILC, 'Fourth Report on the Law of Treaties by Mr. G. G. Fitzmaurice, Special Rapporteur' (1959) Un Doc A/CN.4/120; Fitzmaurice, 'The Law and Procedure of the International Court of Justice, 1951-4: Treaty Interpretation and Other Treaty Points' (n 1006) 210-212.

1070 ILC, 'Third Report on the Law of Treaties, by Sir Humphrey Waldock, Special Rapporteur' (1964) Un Doc A/CN.4/167 and Add. 1-3 54 .

1071 Art. 31-33 VCLT.

1072 ILC, 'Draft Articles on the Law of Treaties With Commentaries' (n 783) 220.

1073 ILC, 'Sixth Report on the Law of Treaties by Sir Humphrey Waldock, Special Rapporteur' (1966) Un Doc A/CN.4/186 and Add. 1, 2/Rev. 1, 3-7 94. 
for being scarce and evasive. ${ }^{1074}$ The decisions of international courts (again, as imperfect as they are $)^{1075}$ also contain references to such canons. ${ }^{1076}$ In 2012, the topic of the 'formation and evidence of customary international law', subsequently changed to 'identification of customary international law', was added to the ILC's agenda. ${ }^{1077}$ The ILC's work, which was completed in $2018,{ }^{1078}$ provides insights into the concerns that interpretative methods are expected to address in international law. It follows on from previous efforts to clarify these methods. ${ }^{1079}$ Starting from the assumption that those who apply CIL need an understanding of the process by which custom is created, the ILC's goal is, similar to the goals of previous ILC projects, ${ }^{1080}$ 'to produce authoritative guidance for those called upon to identify customary international law, including national and international judges'.1081 On the other hand, the Commission cautions against being 'overly prescriptive', and it does not expect to come up with 'hard-and-fast rules' of identification. ${ }^{1082}$ It therefore seeks to find a middle ground between freedom and constraint. ${ }^{1083}$

No comparable project of codification exists with regard to general principles of international law, which makes it difficult to inquire into the origins of the canons governing their identification. However, as I will show, such canons apply to general principles as well (infra, Chapter 6 and Chapter 8, section 3).

1074 August Reinisch and Peter Bachmayer, 'Customary International Law in Austrian Courts' (2013) < papers.ssrn.com/sol3/papers.cfm?abstract_id=2289788>; Besson and Ammann (n 6o).

1075 Gradoni (n 988) 394 ff; Talmon (n 73).

1076 ICJ, Jurisdictional Immunities of the State (Germany v. Italy; Greece intervening), judgment, ICJ Reports 2012, 3 February 2012, 99, at $122 \mathrm{ff}$, para $54 \mathrm{ff}$.

1077 For an overview, see <legal.un.org/ilc/guide/1_13.shtml >.

1078 ILC, 'Draft Conclusions on Identification of Customary International Law, With Commentaries' (n 891). For a diachronic account of the doctrine of CIL, see Jean d'Aspremont, 'The Four Lives of Customary International Law' (2019) 21 International Community Law Review 229.

1079 Eg ILA Committee on Formation of Customary (General) International Law (n 886).

1080 See ibid 4 .

1081 ILC, 'Recommendation of the ILC Working-Group on the Long-Term Programme of Work, Annex A: Formation and Evidence of Customary International Law (Mr. Michael Wood)' (2011) Un Doc A/66/10, 305, para 4. See also ILC, 'First Report on Formation and Evidence of Customary International Law by Special Rapporteur Sir Michael Wood' (n 185) 6, para 14.

1082 See ILC, 'First Report on Formation and Evidence of Customary International Law by Special Rapporteur Sir Michael Wood' (n 185) 7, para 18.

1083 ILC, 'Third Report on Identification of Customary International Law by Michael Wood, Special Rapporteur' (n 294) 2, para 4. 
To conclude, and as is the case with domestic law (supra, 3.1), interpretative methods are reflected in the practice of international law. This practice originally developed them and has sought (and is still seeking) to systematize them. Some norms prescribing the use of methods have been (or are being) codified. Codification increases the predictability, clarity, and consistency of interpretation in international law, while preserving States' interpretative freedom. States, the primary interpreters of international law, refer to such methods and seek to demonstrate that they are guided by them. Interpretative methods are also used by scholars and practitioners to evaluate specific interpretations.

\subsection{The Relationship between the Interpretative Methods of Domestic and International Law}

As emerges from the previous subsections (supra, 3.1 and 3.2), interpretative methods guide the practice of both domestic and international law. To slightly adjust Matthias Goldmann's conclusion regarding the sources of the law, 'thinking in terms of sources'1084 and methods is not peculiar to either domestic or international law: both do. Importantly, and unlike what is often assumed, there is no fundamental difference between interpretative methods in domestic and international law, ${ }^{1085}$ as I will show in more detail (infra, Chapter 6). The basic methods prescribed by the VCLT, for instance, are the same as those that govern statutory and constitutional ${ }^{1086}$ interpretation (ie, textual interpretation, systemic interpretation, teleological interpretation, and historical interpretation). ${ }^{1087}$ Nor do interpretative methods fundamentally

1084 Matthias Goldmann, 'Sources in the Meta-Theory of International Law: Exploring the Hermeneutics, Authority, and Publicness of International Law' in Samantha Besson and Jean d'Aspremont (eds), The Oxford Handbook on the Sources of International Law (Oxford University Press 2017) 5 .

1085 See also BGE 13 O I 312, at 4.1; BGE 135 V 339, at 5.3, and 'Appendix 7. The Interpretation of Treaties, Seventh International Conference of American States, 1933' (1935) 29 American Journal of International Law 1225. Contra André Nollkaemper, 'Grounds for the Application of International Rules of Interpretation in National Courts' in Helmut Philipp Aust and Georg Nolte (eds), The Interpretation of International Law by Domestic Courts: Unity, Diversity, Convergence (Oxford University Press 2016).

1086 Curtis Bradley and Jack Goldsmith, in their textbook on Us foreign relations law, list the methods of constitutional interpretation that are 'most relevant to foreign relations law', ie, originalism, burkeanism/historical gloss, structuralism, prudentialism, and stare decisis. See Bradley and Goldsmith (n 171) 40.

1087 In its commentary of the VCLT, the ILC notes that 'statements can be found in the decisions of international tribunals to support the use of almost every principle or maxim of which use is made in national systems of law in the interpretation of statutes and contracts'. See ILC, 'Draft Articles on the Law of Treaties With Commentaries' (n 783) 218. 
vary from one domestic legal order to the other. ${ }^{1088}$ What varies is mainly the interpretative object and its characteristics, which must be taken into account in the interpretative process.

\section{4}

\section{Three Reasons for Requiring States to Use Interpretative Methods}

The use of, and value attached to, interpretative methods is reflected in domestic and international law (supra, section 3). But what is the rationale for requiring States (including courts) to use specific methods when interpreting the law?

In this section, I mention three compelling reasons why it is necessary to harness the judiciary through interpretative methods (and, one might add, for requiring it to strive to achieve predictability, clarity, and consistency in its reasoning). These reasons pertain to the frequent vagueness of laws (4.1), to the 'counter-majoritarian difficulty' created by judicial review (4.2), and to courts' interpretative power (4.3). These arguments apply (with slight adjustments) to domestic and international law.

By using words such as 'rationale', 'reasons', or 'arguments', I am not evaluating the legitimacy or moral justification of legal norms that prescribe interpretative methods. ${ }^{1089}$ Instead, my aim is to show that there are weighty (empirical, but also legal) reasons for legally requiring States and their courts to use specific methods to interpret domestic and international law, independently from the moral justification of such a legal requirement. However, the reasons I cite in this section provide elements for such a theory of legitimacy.

\subsection{Vagueness \\ 4.1.1 Domestic Law}

One compelling reason why domestic courts must resort to methods to decide cases is that domestic law is often vague when applied to particular issues. Hart famously stated that the law is open textured, ${ }^{1090}$ and that it inevitably becomes indeterminate in practice. ${ }^{1091}$ As Timothy Endicott writes, vagueness

\footnotetext{
1088 MacCormick and Summers (n 1034). On the domestic origins of international interpretative norms (especially rules of logic), see Waibel, "The Origins of Interpretive Canons in Domestic Legal Systems' (n 1059).

1089 On the methodology of the present study, see supra, Introduction, sections 2 and 3.

1090 Hart borrowed this expression from Waismann; see Waismann (n 153) 123.

1091 Hart (n 78) $124 \mathrm{ff}$.
} 
is no pathology, but a feature of the law. ${ }^{1092}$ Vagueness in law is not only a symptom of linguistic indeterminacy. ${ }^{1093}$ It is, as Scott Brewer notes, 'relative to term, language user(s), time of application of term, and "application group" (the set of objects to which the term might be applied).'1094

Domestic constitutions, in particular, are frequently vague. First of all, they are drafted at a high level of generality, since they aim at setting out the basic norms of a given polity without reaching 'the prolixity of a legal code' ${ }^{1095}$ Second, as Michael Klarman observes, 'the debate over permissible sources of [constitutional] interpretation is [...] inconclusive'.1096 Third, constitutions are usually difficult to amend. This can create gaps between their text and contemporary circumstances, gaps which judges may feel compelled to fill through interpretation.

Vagueness, as Timothy Endicott notes, means that 'judicial decisionmaking will in some cases be unconstrained by the law'1097 This should not surprise us, as every domestic polity, in establishing judicial review, accepts at least implicitly that judges will make choices when applying the law. Few would argue that adjudication is value-free, or that the judge is a 'subsumption automaton'. ${ }^{1098}$ Georg Friedrich Puchta's and Bernhard Windscheid's 'Begriffsjurisprudenz' and the French 'école de l'exégèse' have fallen out of favor, at least in their extreme (and often exaggerated) readings. Endorsing what Hart called conceptualism, which consists in denying the existence of interpretative latitude, ${ }^{1099}$ may be tempting for courts wary of securing the social acceptance of their rulings. Yet conceptualism is counter-factual, as it ignores the choices and creativity that characterize judicial decision-making. Worse, it allows courts to hide these choices behind an alleged 'clarity' of the law. If vagueness is negated, courts are less accountable to the polity that has granted them their adjudicatory power.

Does the fact that vagueness cannot be eliminated from the law (and that judges are hence rarely fully constrained) mean that the rule of law is unattainable? ${ }^{1100}$ Vagueness, Endicott explains, is not necessarily 'a deficit' in

\footnotetext{
1092 Endicott (n 8o) 1.

1093 See ibid 5; Brian Bix, Law, Language, and Legal Determinacy (Clarendon Press 1993).

1094 Brewer (n 213) 993.

1095 McCulloch v. Maryland, 17 U.s. 316 (1819), at 407.

1096 Klarman (n 1036) 1724.

1097 Endicott (n 8o) 4.

1098 Regina Ogorek, Aufklärung über Justiz: Richterkönig oder Subsumtionsautomat? Zur Justiztheorie im 19. Jahrhundert (2nd edn, Vittorio Klostermann 2008). See also Frankfurter (n 4) 541.

1099 Hart (n 78$) 129$.

1100 On this issue, see Timothy Endicott, 'The Impossibility of the Rule of Law', Vagueness in Law (Oxford University Press 2000).
} 
the rule of law. However, it can become one 'when it enables authorities to exempt their actions from the reason of the law, or when it makes it impossible to conceive of the law as having any reason distinguishable from the will of the officials.' ${ }^{1101}$ Hence, if judges can demonstrate that their decisions are guided by the interpretative methods the law requires them to use, they are better equipped to rebut such charges.

\subsubsection{International Law}

As mentioned (4.1.1, supra), vagueness has several different causes. The magnitude of these causes is arguably even greater in international law. This increases the discretion of its interpreters.

First, international law is often vague because the sources from which it stems, and the characteristics of these sources, leave room for indeterminacy. ${ }^{1102}$ There can be uncertainty as to whether an 'agreement' qualifies as a 'treaty' under the VCLT, for instance. ${ }^{1103}$ The ascertainment of unwritten law is even less determinate, given the absence of a textual interpretative basis and given the scarce guidance provided by art. 38 ICJ Statute. State practice is difficult to access ${ }^{1104}$ and to review comprehensively. Moreover, the sources of international law are not hierarchical, ${ }^{1105}$ which leaves interpreters with little guidance when norms originating from distinct sources clash.

Second, the fact that States often differ in their legal structure, political organization, socio-cultural characteristics, interests, and policies increases the likelihood of interpretative divergence. ${ }^{1106}$ Of course, diversity does not necessarily generate disagreement. Still, Philip Allott has observed that a treaty is 'a disagreement reduced to writing', 1107 and Detlev Vagts notes that vague treaty provisions are often 'designed to postpone insoluble problems.'1108

\footnotetext{
1101 Endicott (n 80) 5.

1102 Oliver Diggelmann, 'Anmerkungen zu den Unschärfen des völkerrechtlichen Rechtsbegriffs' (2016) 26 Swiss Review of International and European Law 381.

1103 Art. 2(1)(a) VCLT.

1104 ILA Committee on Formation of Customary (General) International Law (n 886) 3.

1105 See however Institut de droit international, 'Problèmes découlant d'une succession de conventions de codification du droit international sur un même sujet' $(1995)<$ www.idiiil.org/idiF/resolutionsF/1995_lis_o1_fr.pdf>, conclusion 11.

1106 Hessler (n 154).

1107 Philip Allott, 'The Concept of International Law' (1999) 10 European Journal of International Law 31, 43 .

1108 Detlev F Vagts, 'Treaty Interpretation and the New American Ways of Law Reading' (1993) 4 European Journal of International Law 472, 476.
} 
International law applies, by definition, to various jurisdictions, and its contextualization is likely to vary depending on the characteristics of these legal orders.

A third cause of vagueness arises with the passage of time. The costs of amending a treaty are high, as such changes require the consent of all parties. ${ }^{1109}$ Yet the context and circumstances in which treaties are interpreted may evolve drastically over time. Judges face vagueness when examining whether the law can be adjusted to contemporary circumstances. The passage of time also creates interpretative challenges when it comes to identifying unwritten international law.

Vagueness is also encouraged by the institutional features of international law, which is governed by the principle of auto-interpretation. In the absence of an international court empowered to adjudicate international legal disputes, States interpret their obligations without being bound by the interpretations of other international legal subjects. The lack of an overarching interpretative authority creates interpretative uncertainty. ${ }^{1110}$

After highlighting these causes of vagueness in international law, some additional remarks about vagueness are in order. First, vagueness can be either deliberate or fortuitous. It is intentional when States collectively enact norms that require further interpretation and, therefore, allow for domestic contextualization, like the provisions of the ECHR. Vagueness is not entirely contingent on the features of the law. Often (although not always), it also results from the interpretative work judges perform (infra, 4.3). Second, in some cases, international law can be precise. This applies, for instance, to treaties aimed at harmonizing an area of the law, eg in trade law, air and space law, or maritime law. The diagnosis of vagueness should not be applied to international law across the board, given the great diversity of its norms. Third, the vagueness of international law can be reduced or prevented, be it on the international plane, ${ }^{1111}$ or in the context of the domestic application of international law. ${ }^{1112}$ As Timothy Endicott stresses, increasing legal determinacy does not necessarily serve justice: precise regulations can be more arbitrary than vague ones. ${ }^{1113}$

1109 Art. 39 ff vCLT.

1110 Paul Guggenheim, 'What Is Positive International Law?' in George A Lipsky (ed), Law and Politics in the World Community: Essays on Hans Kelsen's Pure Theory and Related Problems in International Law (University of California Press 1953) 29.

1111 (Subsidiary) organs of IOs (eg the ILC) and private bodies (eg the Institut de droit international, the ILA, or Harvard Law School) have produced documents that aim at clarifying (and supporting the codification of) international law.

1112 The (non-binding) us Restatement of Foreign Relations Law, for example, provides guidance for the domestic practice of international law.

1113 Endicott (n 8o) $189 \mathrm{f}$. 
However, if vague laws can be interpreted without any constraints, ie, without following a method set out in advance, then vagueness facilitates departures from legality.

To conclude, methods are one way of handling vagueness in domestic and international law. Although they rarely determine interpretative outcomes and do not preclude window-dressing, methods constrain interpreters by requiring them to use specific techniques known to all.

\subsection{Counter-Majoritarian Decisions}

4.2.1 Domestic Law

While there are many competing conceptions of legitimacy, ${ }^{1114}$ democratic legitimacy is a well-established ${ }^{1115}$ yardstick against which judicial decisions are measured by lawyers and non-lawyers alike. Few would deny that in a democracy, 'uncabined judicial rule'1116 is a specter that should be driven away. The need to constrain judicial decision-making (eg by requiring that it conforms to specific methods, but also through other democratic checks) is often traced back to the famous 'counter-majoritarian difficulty' ${ }^{1117}$ In short, in a democracy, unelected judges cannot usurp the powers of the lawmaker and overrule decisions taken by the legislative majority. Instead, they must respect the law.

Interpretative methods require judges to focus on specific features of the law, ie, its wording, purpose, drafting history, and place in the broader legislative scheme. In doing so (and, arguably, especially via textual and historical interpretation), judges show respect for legislative enactments, thereby reducing their own democratic deficit.

\subsubsection{International Law}

Judicial interpretations of international law have counter-majoritarian traits when they disregard sovereign equality (and especially States' equal voice in international lawmaking), or when they ignore other features of the sources of international law. In such cases, judges lack accountability towards the lawmaking States. This risk exists with regard to all sources of international law, ie, treaty law, CIL, and general principles of international law. ${ }^{1118}$

This lack of accountability is encouraged by the characteristics of international lawmaking. Written domestic law is, as French jurist Emile Boutmy

\footnotetext{
1114 Goldsworthy (n 777) 1.

1115 Of course, the way of assessing democratic legitimacy is deeply controversial.

1116 Klarman (n 831) $175^{2}$.

1117 Bickel (n 697) $16 \mathrm{ff}$.

1118 On general principles, for instance, see Jain (n 73) 133 ff.
} 
notes, like 'the work of art that is dated and signed,'1119 namely an object that can be traced back to a single author. International lawmaking, by contrast, involves at least two States (sometimes in the framework of an IO). It often occurs in a decentralized, dispersed, and incremental fashion, which complicates the interpretative process. Even when international lawmaking is institutionalized (eg when a treaty is adopted after a process of negotiations), in most cases, no permanent international lawmaking body can react to States' (or domestic courts') interpretations by changing the law. Moreover, as previously mentioned, States cannot amend treaties unless all parties consent.

Requiring States and their courts to abide by specific methods when they interpret international law is one way of enhancing their accountability. Methods narrow the scope of what constitutes a lawful interpretation, and they compel States to respect the sources of international law.

\subsection{Judicial Politics}

4.3.1 Domestic Law

Partly due to the vagueness of domestic (and especially constitutional) law (supra, 4.1) and to judges' institutional independence from the legislature (4.2), courts enjoy discretion ${ }^{1120}$ when it comes to deciding cases, and they may be tempted to abuse it.

Courts may settle on what can be perceived as bold interpretations. They sometimes interpret domestic laws contra legem, and they have created rights based on ambiguously worded provisions. ${ }^{1121}$ us constitutional legal scholars such as Michael Klarman even argue that some us Supreme Court decisions are explicable 'only in terms of the [...] majority's partisan political preferences',1122 although the Justices (like judges in other countries) forcefully deny it..123

Critical legal scholars have highlighted the creative features of adjudication. Duncan Kennedy for instance challenges Hart's distinction between the law's 'core of settled meaning', within which the law is precise, and its 'penumbra of doubt', ie, the cases in which the law becomes indeterminate. ${ }^{1124}$ Kennedy

\footnotetext{
1119 Emile Gaston Boutmy, Des rapports et des limites des études juridiques et des études politiques (Armand Colin 1889) 8.

1120 On judicial discretion and its relationship to interpretation, see Barradas de Freitas (n 127) 190.

1121 Griswold v. Connecticut, 381 U.s. 479 (1965). On Swiss courts, see Hertig Randall and Chatton (n 441) 393.

1122 Klarman (n 1036) 1724. See also the references in footnote 10 in Petersen ( $\left.\mathrm{n}_{73}\right)$.

1123 Klarman (n 1036) 1724.

1124 Kennedy, 'A Left/Phenomenological Alternative to the Hart/Kelsen Theory of Legal Interpretation' (n 176). On the dialectical relationship between HLA Hart and Duncan
} 
argues that the boundary between the core and the penumbra is not inherent in the features of the law. Rather, in many cases, it is the result of judicial interpretation. The judge is analogous to a worker on a field that is 'open to manipulation': she can, up to a certain extent, 'shape' the law to make it fit the purpose she has in mind. ${ }^{1125}$ While interpretative solutions are presented as objectively correct, objectivity is partly defined by judges themselves.

Kennedy's (and other scholars') critique of adjudication is a powerful reminder of the conscious and unconscious biases of judicial decision-making. It draws attention to, and cautions against, the reality of the practice and the phenomenology of judicial decision-making. It also highlights the need to harness judicial discretion and to prevent arbitrariness, a necessity most legal scholars acknowledge.

One way to move closer to this goal is, again, to require judges to use interpretative methods as guides in their decision-making. Interpretative methods aim at bringing light upon the black box of judicial discretion. They provide a benchmark against which exercises of judicial power can be evaluated and anticipated with reasonable certainty. While methods do not eliminate biases, they make it more difficult for courts to decide based on their own 'sweet will and whims.'.126

\subsubsection{International Law}

In international law, the risk of arbitrary interpretations is arguably even greater than in domestic law. International law is, as already mentioned, governed by the principle of auto-interpretation: in the absence of international dispute settlement bodies that have the authority to review domestic interpretations, States interpret their own obligations without being bound by the interpretations of other subjects of international law. Two States' divergent interpretations are equal in the sense that none trumps the other. Their legal authority is confined to both States' respective legal orders.

Auto-interpretation is a principle with notable exceptions. In some cases, international and regional courts have the power to review States' interpretations, subject to the specific relationship of authority that exists between a

Kennedy, and on the implications of their work for domestic courts' interpretations of international law, see Ammann, 'How Do and Should Domestic Courts Interpret International Law? Insights From the Jurisprudence of H.L.A. Hart and Duncan Kennedy' (n 817).

1125 Kennedy, 'Freedom and Constraint in Adjudication: A Critical Phenomenology' (n 75).

1126 Timothy Endicott, 'The Coxford Lecture: Arbitrariness (in Judicial and Public Authority Decision Making)' (2014) 27 Canadian Journal of Law and Jurisprudence 49. 
given international adjudicatory body and States. ${ }^{1127}$ Nonetheless, while international courts have been 'proliferating'1128 in recent decades, giving rise to an equally prolific scholarship, ${ }^{1129}$ the practical significance of auto-interpretation should not be underestimated.

Auto-interpretation increases the interpretative discretion of States and their courts in several respects. First, the fact that States are judges in their own cause creates risks of partiality. Realist scholars consider it irrational for States to interpret their obligations in a way that jeopardizes their own interests. ${ }^{1130}$ Courts too can be tempted to base their decisions on prudential considerations. Congyan Cai writes about the Chinese 'judicial policy toward international law',1131 and similar tendencies exist in other domestic courts. ${ }^{1132}$ Another risk is that of bootstrapping, or of self-referential interpretations: courts may ascertain international law primarily based on their own (or their State's) practice, as opposed to also referring to the practice of other States.1133

Second, and relatedly, States and their organs might disregard the sources of international law (see Chapters 7 and 8, infra). ${ }^{1134}$ Such flaws are deeply problematic, given that States, in such cases, are no longer interpreting the law under consideration. Taking interpretative methods seriously means accounting for the essential features of international law and for the process by which it came into being. While auto-interpretation leaves room for divergent interpretations, it does not entail that States can freely choose their interpretative methods. States must respect secondary norms of international law if they are to interpret international law, as opposed to doing something else.

1127 The ICJ's jurisdiction is conditional upon a declaration of the parties pursuant to art. 36 ICJ Statute, the ICC's jurisdiction is complementary to that of domestic institutions (art. 17 ICC Statute), and interventions of the ECtHR are subsidiary to those of domestic institutions (art. 35(1) ECHR; see also Protocol 15 to the ECHR (yet to enter into force)).

1128 Benedict Kingsbury, 'Foreword: Is the Proliferation of International Courts and Tribunals a Systemic Problem?' (1999) 31 New York University Journal of International Law and Politics 679 .

1129 Cesare Romano, Karen Alter, and Yuval Shany (eds), The Oxford Handbook of International Adjudication (Oxford University Press 2014).

1130 Jack L Goldsmith and Eric A Posner, The Limits of International Law (Oxford University Press 2005). See also Gross (n 844) 287.

1131 Congyan (n 44) 270.

1132 Medellín v. Texas, $55^{2}$ U.s. 491 (2008).

1133 Besson and Ammann (n 6o). This tendency has been confirmed by empirical work, see Bart MJ Szewczyk, 'Customary International Law and Statutory Interpretation: An Empirical Analysis of Federal Court Decisions' (2014) 82 George Washington Law Review 1118,1133 . See also Chapters $7-8$ (infra).

1134 Eg Vagts (n 1108) 481. 
To conclude, given the vagueness of international law (4.1), the countermajoritarian features of judicial interpretation (4.2), and the prevalence of auto-interpretation (4.3), the interpretation of international law needs 'shared standards for estimating which professional work is valuable.'1135 It needs them just as - and arguably even more than - the interpretation of domestic law and other interpretative practices do.

While there is a case for constraining the power of courts through interpretative methods (supra, section 4), many lawyers and scholars are, for various reasons, skeptical about interpretative methods, and therefore also about efforts to clarify and emphasize them. Skepticism has especially increased under the influence of legal realism and, in continental Europe, with the rise of postmodern thought, although many scholarly strands highlight the weaknesses of interpretative methods. ${ }^{1136}$ Once again, common critiques raised in international law roughly mirror the domestic ones.

Mainstream challenges against interpretative methods pertain to the fact that norms prescribing the use of interpretative methods are just as vague as other laws (5.1), that they are self-defeating, because they are shaped by the very actors they are supposed to constrain (5.2), and that an emphasis on methods neglects interpretative outcomes (5.3). I refer to these objections as the 'vague methods' objection, the 'self-made methods' objection, and the 'outcome over process' objection. The three objections are more complex than what can be elucidated here, and they do not exhaust the challenges raised against interpretative methods. For reasons of scope, I focus on these common critiques, and I respond to each of them.

\subsection{The 'Vague Methods' Objection}

Many theorists of domestic law doubt that methods can constrain judicial reasoning. They consider that methods provide judges with convenient legitimizing devices that these judges can twist. Hart himself notes that methods cannot prevent judicial discretion, since methods, like any law, need to be interpreted. ${ }^{1137}$ This observation is made by many

\footnotetext{
1135 Donald G Marshall, 'Literary Interpretation' in Joseph Gibaldi (ed), Canonicity and Textuality (Modern Languages Association of America 1992) 173.

1136 Hart (n 78) 126.

1137 See ibid.
} 
scholars, ${ }^{1138}$ eg by Stanley Fish ${ }^{1139}$ in response to Owen Fiss's account of socalled 'disciplining rules' in interpretation, both inside and outside the law. ${ }^{1140}$ The legal realists (like the 'political realists') ${ }^{1141}$ have stressed that methods do not determine the outcome of judicial decision-making, that they leave room for considerations of policy, ${ }^{1142}$ and that judges use methods for the purpose of post hoc rationalization. ${ }^{1143}$ Critical legal scholars also highlight the influence of 'ideological' considerations on judicial decisions. ${ }^{1144}$ Postmodern thinkers view the interpreter (and the interpretative object) as a matrix of meaning. Jacques Derrida for instance emphasizes the radical indeterminacy of interpretative objects, and he describes the interpretative process as an infinite regress from one text to another. ${ }^{1145}$ Such views have been influential beyond literary theory, ${ }^{1146}$ including in legal scholarship. ${ }^{1147}$ Without necessarily being skeptical, scholars have shown the pitfalls and 'leading vices'1148 of interpretative reasoning. Even conservative legal scholars emphasize that judicial decisions result from 'interpretive choice.'1149

In international law, interpretative methods leave room for discretion as well. Martti Koskenniemi argues that the sources of international law cannot be identified in an apolitical way. ${ }^{1150}$ Common norms do not eliminate the need for evaluation, and hence reliance on 'essentially contested - political - principles.' ${ }^{1151}$ International law, according to Helmut Aust, only requires

1138 Karl N Llewellyn, 'Remarks on the Theory of Appellate Decision and the Rules and Canons About How Statutes Are to Be Construed' (1950) 3 Vanderbilt Law Review 395; Bankowski and others (n 132) 15 .

1139 Stanley Fish, 'Fish v. Fiss' (1984) 36 Stanford Law Review 1325.

1140 Fiss (n 1029).

1141 On this topic, see Evan Criddle, "The Vienna Convention on the Law of Treaties in U.s. Treaty Interpretation' (2004) 44 Virginia Journal of International Law 431, $470 \mathrm{f}$.

1142 Holmes (n 22); Tushnet (n 777) 5 o.

1143 Klarman (n 831).

1144 Kennedy, A Critique of Adjudication ( $\mathrm{n}_{7} 8$ ).

1145 Eg Jacques Derrida, 'Signature, événement, contexte', Communication au Congrès international des Sociétés de philosophie de langue française (Montreal 1971). See also Jacques Derrida, 'Le langage (Le Monde au téléphone)' Le Monde Dimanche (Spring 1982);Jacques Derrida, Mémoires : pour Paul de Man (Galilée 1988). I am grateful to Yousif M. Qasmiyeh for drawing my attention to these other pieces.

1146 Sontag (n 996) 106.

1147 Amstutz and Niggli (n 105).

1148 MacCormick and Summers (n 1034) $539 \mathrm{ff}$.

1149 Vermeule (n 76$)$.

1150 See (with regard to CIL): Koskenniemi (n 1064) 25 f.

$115^{1}$ See ibid 7 . 
'convergence at a very high level of abstraction.'1152 The ascertainment of the object and purpose ${ }^{1153}$ of a treaty, for instance, is viewed by some scholars as an 'enigma'.1154 Similar difficulties apply to other methods listed in the VCLT. Regarding unwritten international law, Jean d'Aspremont observes that today, 'the intellectual prison of custom seems to be gradually transformed into a large dance floor where (almost) every step and movement is allowed or, at least, tolerated'.1155 Custom is deemed an 'untid[y]' source,, 1156 and the ILC's draft conclusions on custom have been criticized for being too vague, and therefore of limited practical use. ${ }^{1157}$

These various criticisms and observations touch upon an important issue: norms about interpretative methods limit judicial discretion only up to a certain point. Even the General State Laws for the Prussian States did not succeed in regulating every possible case in advance. As Mark Tushnet points out, 'there are no institutional mechanisms for committing judges to particular interpretive methods'.1158 Courts enjoy some leeway at all stages of the interpretative process, be it when choosing what methods to use at what stage of their reasoning, when applying these methods, when weighing the results yielded by different methods and, finally, when drafting their rulings. ${ }^{1159}$

What the critique overlooks is, first, that the fact that methods are elastic and that judges might (and sometimes do) bend them does not demonstrate that they are not worth imposing on judges. People break the law, yet States have laws nonetheless. Of course, there is room for improvement as regards States' use of interpretative methods. ${ }^{1160} \mathrm{I}$ am not arguing that interpretative methods are risk-free. However, judges' fallibility does not demonstrate that interpretative constraints should be discarded.

$115^{2}$ Helmut Philipp Aust, 'Between Universal Aspiration and Local Application: Concluding Observations' in Helmut Philipp Aust and Georg Nolte (eds), The Interpretation of International Law by Domestic Courts: Unity, Diversity, Convergence (Oxford University Press 2016) 337 .

1153 Art. 31(1) VCLT.

1154 Isabelle Buffard and Karl Zemanek, 'The "Object and Purpose” of a Treaty: An Enigma?' (1998) 3 Austrian Review of International \& European Law 311.

1155 Jean d'Aspremont, 'Customary International Law as a Dance Floor: Part I' (EJIL: Talk!, 2014) <www.ejiltalk.org/customary-international-law-as-a-dance-floor-part-i/>.

1156 Hugh Thirlway, The Sources of International Law (Oxford University Press 2014) 59.

1157 Sienho (n 96o) $8 \mathrm{f}$.

$115^{8}$ Tushnet (n 777) 51 .

1159 Judicial decisions may or may not accurately reflect actual processes of deliberation. See ibid 48 .

116o Talmon (n 73); Iovane (n 182). 
Secondly, the critique rightly highlights that evaluative judgments cannot be eliminated from judicial decision-making. In fact, they are even necessary to prevent tyranny. On the other hand, the objection neglects that such value judgments must be kept in bounds. Requiring that courts respect specific methods is one way of doing so. While methods do not eliminate the risk of arbitrariness, they marginalize at least some justifications that could be submitted by courts in support of a given decision. Methods also provide a basis to appraise, contest, and defend judicial decisions.

Thirdly, and paradoxically, the objection demands too much from interpretative methods. It forgets that judges' compliance with the law cannot merely be achieved through interpretative norms. Compliance also depends on the attitude of the law's interpreters, ${ }^{1161}$ and on the stringency with which other participants in the practice (including scholars) criticize deviations from these mandatory canons.

\subsection{The 'Self-Made Methods' Objection}

Interpretative methods also trigger skepticism because States (and judges) at least partly define the constraints that limit their own interpretations. In domestic law, Duncan Kennedy points out that the distinction between the Hartian 'penumbra of doubt' and 'core of settled meaning' is often drawn (and can potentially be shifted) by the judge. ${ }^{1162}$ This also applies to interpretative methods, which - just like the rules of a game can be used to the player's advantage - can be bent to fit the interpreter's preferences and to support a given outcome. In many legal orders, interpretative methods are the product of judicial lawmaking, not of legislative action (supra, 3.1).1163 Because methods can constrain interpreters but also, to some extent, be shaped and adjusted by them, their use can be a virtue as well as a vice.

Similarly, in international law, methods are shaped by the very entities they are primarily supposed to limit, namely States. '[T]he closer to state practice an argument is, the less normative and the more political it seems', Martti Koskenniemi writes. ${ }^{1164}$ But then, Ingo Venzke asks, '[h]ow can we understand

1161 On judicial integrity, see Hannah Arendt, 'Thinking and Moral Considerations: A Lecture' (1971) 38 Social Research 417.

1162 Kennedy, 'A Left/Phenomenological Alternative to the Hart/Kelsen Theory of Legal Interpretation' (n 176).

1163 For codifications of these methods, however, see art. 6 of the Austrian Civil Code of 1 June 1811; art. 12 of the Italian Civil Code of 16 March 1942. See also the references in Waibel, 'Principles of Treaty Interpretation: Developed for and Applied by National Courts?' (n 183) $27 \mathrm{f}$.

1164 Koskenniemi (n 1064) 8. 
interpretation as constrained by rules if it is that same practice that creates the rules?'1165

The aforementioned criticism underlines an important feature of interpretative methods. Methods, qua secondary norms, are first and foremost customary. They are shaped by those whose legal duty it is to apply and to respect the law. As regards methods that have been codified, States and their officials are involved in the codification process as well. On the other hand, the critique neglects a range of points.

First, it is doubtful that other actors are better placed than State institutions when it comes to defining interpretative methods. This is especially the case in international law, where State sovereignty is a pressing concern. Granted, methods should be such that they can truly constrain official (and judicial) decision-making, rather than being vulnerable to being bent by those they are meant to constrain. However, their constraining effect depends not only on their content and on the way these methods are established, but also - and arguably even more so - on the mechanisms deployed to monitor their respect.

Second, in international law, methods are shaped by States collectively. They cannot be defined by one State unilaterally. Moreover, the ILC has codified and systematized interpretative methods in international law, thereby imposing an external constraint on States.

Third, there are checks on the way interpretative methods are applied, even in international law, and despite the fact that these checks are informal and decentralized. Interpretative methods are one of the main yardsticks by which domestic rulings are evaluated on the international plane.

Fourth, auto-interpretation is not synonymous with an 'auto-determination of interpretative methods' ${ }^{1166}$ Granted, States are relatively free within their own jurisdiction, and it is doubtful that international law has 'one true meaning' that must be ascertained by domestic courts 'untrammeled by notions of [their] national culture.'1167 The methods of the VCLT, for instance, do not aim at harmonizing the outcome of treaty interpretation. This notwithstanding, there are methods that international law requires States to follow when they interpret their obligations.

1165 Venzke, How Interpretation Makes International Law: On Semantic Change and Normative Twists (n 126) $54 \mathrm{f}$.

1166 Besson and Ammann (n 97).

1167 Secretary of State for the Home Department, Ex Parte Adan R v. Secretary of State for the Home Department Ex Parte Aitseguer, R v. [2000] U KHL 67; [2001] 2 WLR 143; [2001] 1 All ER 593 (19 December 2000) (Lord Steyn). 


\subsection{The 'Outcome Over Process' Objection}

Without necessarily being skeptical of interpretative methods, it can be argued that regardless of the methods domestic courts use, what matters is the interpretative result.

In domestic law, some Swiss lawyers believe that theorizing judicial interpretation is a superfluous academic exercise. The pragmatic methodology of the Swiss Federal Tribunal, they claim, has proven itself. ${ }^{1168}$ In the United States, Michael Klarman considers it plausible that 'history's verdict on a [US] Supreme Court ruling depends more on whether public opinion ultimately supports the outcome than on the quality of the legal reasoning or the craftsmanship of the Court's opinion.'1169 In the United Kingdom as well, it is 'not infrequent[ly] suggest[ed] that what is important is not what the courts say about statutory interpretation, but what they in fact decide in regard to the statutes which come before them.'1170 A related argument consists in saying that what matters is that the judgment achieves a specific result, eg (depending on what normative position one endorses), that it precludes grave violations of fundamental rights or that it protects democratic decisions. A strict adherence to methodological standards may, in some cases, prevent such a result. This argument is reflected in John Dewey's claim that interpretation must be informed by policy, and that legal norms are tools that must be in service of social needs. ${ }^{1171}$ Focusing on interpretative methods could hence be criticized for dealing solely with 'façade legitimation,, ${ }^{1172}$ and not with legitimacy in the proper sense, however legitimacy is defined.

From the perspective of international law as well, it can be argued that what matters for international law is less the interpretative process than the result reached by States (inter alia via their courts). Pursuant to the idea that in international law, the State is a 'black box,',173 what matters from the vantage point of international law is that States abide by their international obligations. ${ }^{1174}$ How they choose to do so, however, is left for them to decide.

The 'outcome over process' objection raises - once again - concerns that should not be hastily swept aside. Focusing on the outcome of judicial decision-making is helpful, as it prevents losing sight of the consequences of

\footnotetext{
1168 Walter (n 118).

1169 Klarman (n 1036) 1722. See also ibid $1747 \mathrm{ff}$.

1170 The Interpretation of Statutes ( $\left.n_{54}\right) 5$.

1171 Dewey (n 777).

1172 Bankowski and others (n 132) 16.

1173 Ferdinandusse (n 856).

1174 Art. 26 fvelt.
} 
these decisions. Domestic rulings, to be socially accepted and to be obeyed in the long run, need to deliver more than mere conformity to methodological standards.

Still, the 'outcome over process' criticism seems exaggerated on more than one count. First, process and outcome are not disconnected: they are two sides of the same coin. Using interpretative methods that are required by law can influence the interpretative outcome, even if this is not always the case. Even when the outcome remains unchanged, the interpretative process is important, as it explains and seeks to justify the interpretative result. The concept of 'interpretation' itself refers both to the interpretative process and to its result.

Second, international law is not blind to interpretative outcomes. The VCLT's methods emphasize the parties' duty to interpret treaties in 'good faith', holistically, and so as to avoid 'ambiguous or obscure' and 'manifestly absurd or unreasonable' interpretative results. ${ }^{1175}$ Thus, the VCLT regulates both the interpretative process and its outcome.

Third, the pervasiveness of disagreement in interpretation, judicial interpretation, and international law makes it essential to agree on common methods in order to evaluate the merits of incompatible decisions.

Standard objections to having methods of judicial interpretation should not be dismissed quickly. They recall aspects related to the phenomenology of judicial decision-making. They also raise the difficult and controversial question of the outcome that judicial decisions should achieve. Yet little is gained by abandoning methodological imperatives in judicial decision-making and, thus, by opening the door of the courtroom wider to arbitrary decision-making. Of course, interpretative methods are not a panacea. Interpreters need to choose among competing interpretative results yielded by different methods. Methods must be applied in a predictable, clear, and consistent way. If they are not, they become convenient yet deceitful 'judicial marketing' tools. ${ }^{1176}$ In short, we should not overestimate what interpretative methods can achieve, nor should we downplay their contribution to legality in domestic and international law.

1175 Art. 31 fvClt.

1176 Isabelle Van Damme, 'Treaty Interpretation by the wTo Appellate Body' (2010) 21 European Journal of International Law 605, 640 . 